CLINICAL STUDY

\title{
Two common genetic variants near nuclear-encoded OXPHOS genes are associated with insulin secretion in vivo
}

\author{
Anders H Olsson ${ }^{1}$, Tina Rönn ${ }^{1}$, Claes Ladenvall ${ }^{1}$, Hemang Parikh ${ }^{1,2}$, Bo Isomaa ${ }^{3,4}$, Leif Groop ${ }^{1}$ and Charlotte Ling ${ }^{1}$ \\ ${ }^{1}$ Department of Clinical Sciences, Lund University Diabetes Center, CRC, Lund University, Scania University Hospital, 20502 Malmö, Sweden, \\ ${ }^{2}$ Laboratory of Translational Genomics, Division of Cancer Epidemiology and Genetics, National Cancer Institute, National Institutes of Health, Bethesda, \\ Maryland 20877, USA, ${ }^{3}$ Folkhälsan Research Center, Biomedicum Helsinki, O0014 University of Helsinki, Helsinki, Finland and ${ }^{4}$ Department of Social \\ Services and Health Care, 68601 Jakobstad, Finland
}

(Correspondence should be addressed to C Ling; Email: charlotte.ling@med.lu.se)

\begin{abstract}
Context: Mitochondrial ATP production is important in the regulation of glucose-stimulated insulin secretion. Genetic factors may modulate the capacity of the $\beta$-cells to secrete insulin and thereby contribute to the risk of type 2 diabetes.

Objective: The aim of this study was to identify genetic loci in or adjacent to nuclear-encoded genes of the oxidative phosphorylation (OXPHOS) pathway that are associated with insulin secretion in vivo. Design and methods: To find polymorphisms associated with glucose-stimulated insulin secretion, data from a genome-wide association study (GWAS) of 1467 non-diabetic individuals, including the Diabetes Genetic Initiative (DGI), was examined. A total of 413 single nucleotide polymorphisms with a minor allele frequency $\geq 0.05$ located in or adjacent to 76 OXPHOS genes were included in the DGI GWAS. A more extensive population-based study of 4323 non-diabetics, the PPP-Botnia, was used as a replication cohort. Insulinogenic index during an oral glucose tolerance test was used as a surrogate marker of glucose-stimulated insulin secretion. Multivariate linear regression analyses were used to test genotype-phenotype associations.

Results: Two common variants were identified in the DGI, where the major C-allele of rs606164, adjacent to NADH dehydrogenase (ubiquinone) 1 subunit C2 (NDUFC2), and the minor G-allele of rs1323070, adjacent to cytochrome $c$ oxidase subunit VIIa polypeptide 2 (COX7A2), showed nominal associations with decreased glucose-stimulated insulin secretion $(P=0.0009$, respective $P=0.003)$. These associations were replicated in PPP-Botnia $(P=0.002$ and $P=0.05)$.

Conclusion: Our study shows that genetic variation near genes involved in OXPHOS may influence glucose-stimulated insulin secretion in vivo.
\end{abstract}

European Journal of Endocrinology $164765-771$

\section{Introduction}

Type 2 diabetes is a heterogeneous disease where multiple genes and environmental factors combine to cause the disease. Genetic factors may directly affect the risk of type 2 diabetes by modulating the capacity of the $\beta$-cells to secrete insulin and/or by inducing insulin resistance in target tissues. Mitochondrial dysfunction has been suggested to contribute to both impaired insulin secretion and insulin resistance $(1,2)$. In pancreatic $\beta$-cells, mitochondria play a key role in regulating insulin secretion. Oxidative phosphorylation (OXPHOS) by the respiratory chain, which contains five enzyme complexes embedded in the mitochondrial inner membrane, is coupled to conversion of ADP into ATP. Elevated plasma glucose levels will cause a rise in the $\beta$-cell ATP/ADP ratio, which is a main trigger for insulin secretion (3). Mitochondrial dysfunction could thereby lead to impaired insulin secretion from the $\beta$-cells and subsequently to an increased risk of type 2 diabetes. The multi-protein complexes in the OXPHOS system contain $\sim 90$ protein subunits encoded by both the nuclear and mitochondrial genomes (4), where the mitochondrial genome encodes 13 of the subunits present. A previous study from our group has shown the mRNA expression of peroxisome proliferatoractivated receptor gamma coactivator 1 alpha (PPARGC1A), a master regulator of mitochondrial genes, to be reduced in islets from patients with type 2 diabetes and this reduction correlates with impaired glucose-stimulated insulin secretion (5). In addition, a common polymorphism (rs8192678) influences PPARGC1A mRNA expression and insulin secretion in the human islets. Even though a mutation in mitochondrial DNA has been found in a rare but specific form of diabetes (maternally inherited diabetes and commercial use, distribution, and reproduction in any medium, provided the original work is properly cited. 
deafness, MIDD), common variation in mitochondrial DNA has not been associated with metabolic diseases $(6,7)$. Mitochondrial genes encoded by the nuclear genome have been implicated in the pathogenesis of diabetes $(8,9)$. However, only a small number of studies have reported whether polymorphisms in nuclear-encoded genes involved in OXPHOS influence the risk of the disease $(5,10-12)$, e.g. a polymorphism in NDUFB6 (rs540467) has been associated with increased risk of type 2 diabetes (12).

Recent genome-wide association studies (GWASs), including the Diabetes Genetic Initiative (DGI), have provided new insights into the nature of the genetic factors involved in the pathogenesis of type 2 diabetes (13). Since mitochondrial ATP production is important in the regulation of glucose-stimulated insulin secretion, we examined if polymorphisms in or near nuclear-encoded genes of the respiratory chain are associated with insulin secretion, using data from the DGI GWAS (13).

\section{Subjects and methods}

\section{Study populations}

The DGI is a case-control-based study, where patients with type 2 diabetes, geographically matched controls and discordant sibships were selected from Finland and Sweden (13). Patients with type 2 diabetes were classified according to WHO (1999) criteria with fasting plasma glucose $\geq 7.0 \mathrm{mmol} / \mathrm{l}$ or a $2 \mathrm{~h}$ glucose $\geq 11.1 \mathrm{mmol} / \mathrm{l}$ during an oral glucose tolerance test (OGTT) and 1464 patients were included in the DGI. Non-diabetic subjects were defined as normal glucose tolerant, with fasting plasma glucose $<6.1 \mathrm{mmol} / \mathrm{l}$ and $2 \mathrm{~h}$ glucose $<7.8 \mathrm{mmol} / \mathrm{l}$. Population-based non-diabetic subjects had no first-degree relatives with type 2 diabetes and included 1467 individuals (Table 1) (13). Only non-diabetic subjects were included in the current study.

Table 1 Clinical characteristics of non-diabetic participants in the DGI and the PPP-Botnia. Data are expressed as mean \pm s.D. or median (IQR). Insulinogenic index: calculated as ((insulin at $30 \mathrm{~min}$-insulin at $0 \mathrm{~min}$ )/(glucose at $30 \mathrm{~min}$-glucose at $0 \mathrm{~min}$ )). HOMA-IR: calculated as ((glucose at $0 \mathrm{~min} \times$ insulin at $0 \mathrm{~min}) / 22.5)$.

\begin{tabular}{lll}
\hline Characteristics & DGI & PPP-Botnia \\
\hline$n$ (male/female) & $1467(707 / 760)$ & $4323(2043 / 2280)$ \\
Age (years) & $58.8 \pm 10.1$ & $47.6 \pm 15.2$ \\
BMI (kg/m²) & $26.6 \pm 3.7$ & $26.3 \pm 4.3$ \\
Fasting glucose (mmol/l) & $5.3 \pm 0.5$ & $5.3 \pm 0.6$ \\
Glucose 30 min (mmol/l) & $8.3 \pm 1.5$ & $8.3 \pm 1.6$ \\
Glucose 120 min (mmol/l) & $5.6 \pm 1.3$ & $5.2 \pm 1.6$ \\
Fasting insulin (mU/l) & $5.2(4.3)$ & $5.3(4.2)$ \\
Insulin 30 min (mU/l) & $50.2(48.9)$ & $50.4(38.3)$ \\
Insulin 120 min (mU/l) & $36.2(29.7)$ & $23.7(26.2)$ \\
Insulinogenic index & $14.1(14.8)$ & $15.9(16.1)$ \\
HOMA-IR & $1.46(1.08)$ & $1.26(1.04)$ \\
\hline
\end{tabular}

www.eje-online.org
Prevalence, Prediction and Prevention of diabetes (PPP-Botnia) is a population-based study in the Botnia region of Western Finland (14). The participants were aged 18-75 years (mean age $48.4 \pm 15.6$ years). Diagnosis of type 2 diabetes was confirmed from subject records or on the basis of fasting plasma glucose concentration $\geq 7.0 \mathrm{mmol} / \mathrm{l}$ and/or $2 \mathrm{~h}$ glucose $\geq 11.1 \mathrm{mmol} / \mathrm{l}$. Only non-diabetic subjects $(n=4323)$ were included in the current study, where 612 (14\%) had fasting plasma glucose levels between 6.1 and $6.9 \mathrm{mmol} / \mathrm{l}$ (Table 1).

All participants gave written informed consent for the studies and the local ethics committees approved the protocols.

\section{Assays and measurements}

Blood samples for measurements of plasma glucose and serum insulin concentrations were drawn at 0,30 and $120 \mathrm{~min}$ of the $75 \mathrm{~g}$ OGTT in both DGI and PPP-Botnia.

Plasma glucose was measured in DGI with a glucose oxidase method (Beckman Glucose Analyzer, Beckman Instruments, Fullerton, CA, USA) and in PPP-Botnia with a glucose dehydrogenase method (HemoCue, Ängelholm, Sweden). Three different methods for measurement of insulin concentrations were used in both DGI and PPP-Botnia: RIA (Pharmacia), enzyme linked immunoassay (DAKO Diagnostics Ltd, Cambridgeshire, UK) and fluoroimmunoassay (Delphia, PerkinElmer Finland, Turku, Finland). The Pharmacia and Delphia values were transformed into 'Dako' values using validated correction coefficients.

$\beta$-cell function and glucose-stimulated insulin secretion were assessed as insulinogenic index during an OGTT ((insulin at $30 \mathrm{~min}-$ insulin at $0 \mathrm{~min}) /(\mathrm{glu}-$ cose at $30 \mathrm{~min}-$ glucose at $0 \mathrm{~min})$ ) (15). Insulin resistance estimated by the homeostasis model assessment (HOMA-IR) was calculated as ((glucose at $0 \mathrm{~min} \times$ insulin at $0 \mathrm{~min}) / 22.5)$. $\beta$-Cell function was also assessed in PPP-Botnia as disposition index, insulin secretion adjusted for insulin resistance (insulinogenic index/HOMA-IR).

\section{Identification of single nucleotide polymorph- isms in the DGI GWAS}

We aimed at identifying single nucleotide polymorphisms (SNPs) situated in a region $25 \mathrm{~kb}$ upstream and $25 \mathrm{~kb}$ downstream of nuclear-encoded OXPHOS genes with a minor allele frequency $(\mathrm{MAF}) \geq 0.05$, showing nominal associations $(P \leq 0.01)$ with insulinogenic index in non-diabetic subjects in the DGI GWAS (13). Identified polymorphisms were ranked based on the $P$ values of genotype-phenotype association. The GeneChip Human Mapping 500K Array Set (Affymetrix, Inc., Santa Clara, CA, USA) used in the DGI GWAS has coverage in the CEU HapMap population $\left(r^{2} \leq 0.8\right)$ of $67 \%$, based on single marker test. In the DGI GWAS, 
413 SNPs within or near 76 OXPHOS genes fulfilled the MAF criteria (Supplementary Table 1, see section on supplementary data given at the end of this article) and nine of these SNPs were also nominally associated with insulinogenic index $(P \leq 0.01)$. The two top hits were selected for follow-up in an independent cohort.

\section{Genotyping}

In the DGI GWAS, genotyping was performed using Affymetrix 500K chip array (13). In PPP-Botnia, rs606164 and rs1323070 were genotyped using allelic discrimination assays on the ABI 7900 platform (C_2983373_10 and C_3073719_10, Applied Biosystems, Foster City, CA, USA). The genotyping success rates were $>95.5 \%$ and the concordance rate was $100 \%$ based on $4.2 \%$ duplicate comparisons.

\section{Statistical analyses}

Linear regression analyses were performed to test genotype-phenotype associations, assuming additive genetic models in both DGI and PPP-Botnia. Phenotype values were logarithmically transformed to fit a normal distribution in both cohorts before analyses.

In DGI, z-scores of insulinogenic index were prepared separately by gender and recruiting region (Botnia, Skara, Malmö or Helsinki) and regressed against genotype adjusted for age, log body mass index (BMI) and type of insulin measurement. Unrelated individuals and siblings were included in this analysis. To correct for inflation caused by inclusion of related individuals, the genomic control inflation factor based on the median test statistic was estimated, and $P$ values based on the test statistic adjusted by this factor are reported (13).

In PPP-Botnia, the log-transformed phenotype values were regressed against genotype adjusted for age, sex and BMI.
All analyses were carried out in non-diabetic individuals. Results are presented as median (interquartile range) or $\beta$ coefficient (s.e.m.). Statistical analyses were performed using SPSS version 17 for Windows (SPSS, Chicago, IL, USA) or using STATA/SE 10.0 (STATA Corp. LP, College Station, TX, USA).

\section{Results}

\section{Identification of genetic loci associated with insulin secretion}

To find genetic loci associated with insulin secretion in or adjacent to nuclear-encoded genes of the respiratory chain, we examined data from the DGI GWAS (13) (Table 1). Nine SNPs representing six genes were identified based on a MAF $\geq 0.05$, nominal associations to insulinogenic index with $P \leq 0.01$ and they are located in regions of $25 \mathrm{~kb}$ upstream or downstream of OXHPOS genes (Table 2). Region plots of the six identified OXPHOS genes are presented together with $-\log 10 P$ values of all SNPs within these regions from the DGI GWAS as well as Haploview presentations of the LD-structure based on HapMap data (Supplementary Figure 1A-F, see section on supplementary data given at the end of this article). Based on the lowest $P$ values, two SNPs were selected for follow-up: rs606164, $12 \mathrm{~kb}$ upstream of NDUFC2, and rs1323070, $24 \mathrm{~kb}$ downstream of COX7A2. The major C-allele of rs606164 and the minor G-allele of rs1323070 are nominally associated with decreased glucose-stimulated insulin secretion during an OGTT (insulinogenic index) in nondiabetic subjects of DGI (rs606164: $\beta-0.21 \pm 0.062$, $P=0.0009$ and rs1323070: $\beta-0.14 \pm 0.046$, $P=0.003)$. The common variant rs606164 was not in LD with any of the other two SNPs identified in DGI located adjacent to NDUFC2 (Table 2 and Supplementary Figure 1A, see section on supplementary data given at the end of this article). None of the variants

Table 2 SNPs identified from DGI GWAS located in a region of $\sim 25 \mathrm{~kb}$ upstream or downstream of OXHPOS genes with an association to insulinogenic index in non-diabetic individuals of DGI with $P \leq 0.01$ and MAF $\geq 0.05$. In DGI $P$ values are based on linear regression to test association between genotype and insulinogenic index $z$-score with the covariates gender, recruiting region, age, BMI and type of insulin measurement. A genomic control inflation factor was used to adjust for related individuals.

\begin{tabular}{lclccr}
\hline SNP & Chromosome & \multicolumn{1}{c}{$\begin{array}{c}\text { Nearest } \\
\text { OXPHOS gene }\end{array}$} & $\begin{array}{c}\text { Alleles } \\
\text { (major/minor) }\end{array}$ & MAF & $\beta($ s.E.M.)
\end{tabular}

MAF, minor-allele frequency.

${ }^{a}$ Allele denoted in bold associated with decreased insulinogenic index. 
were associated with type 2 diabetes in the casecontrol-based study of DGI GWAS or insulin resistance (HOMA-IR) in non-diabetic subjects of DGI (13) (Supplementary Table 1, see section on supplementary data given at the end of this article).

\section{Insulin secretion in vivo}

We next investigated whether the NDUFC2 variant, rs606164, and COX7A2 variant, rs1323070, were associated with insulin secretion in a more extensive replication cohort, the PPP-Botnia Study (14) (Table 1). In line with the findings in DGI, C-allele carriers of rs606164 showed decreased insulinogenic index in the PPP-Botnia study $(\beta-0.070 \pm 0.022, P=0.002)$ (Table 3). Moreover, G-allele carriers of rs1323070 showed a nominal association with insulinogenic index in PPP-Botnia $(\beta-0.040 \pm 0.021, P=0.05)$ (Table 3). Disposition index is an additional assessment of $\beta$-cell function that considers the insulin resistance-secretion relationship. When analysing disposition-index, C-allele carriers of rs606164 and G-allele carriers of rs1323070 also showed a decreased insulin secretion adjusted for insulin resistance in PPP-Botnia (rs606164: $\beta$ $-0.066 \pm 0.023, P=0.007$; rs1323070: $\beta-0.040$ $\pm 0.019, P=0.03)$. Neither rs606164 nor rs1323070 was associated with HOMA-IR in PPP-Botnia $(P=0.79$ and $P=0.57$, respectively).

\section{Discussion}

In this study, we have demonstrated that two common polymorphisms, rs606164 adjacent to NDUFC2 and rs1323070 adjacent to COX7A2, are associated with insulin secretion in vivo. Insulin secretion was measured as insulinogenic index at $30 \mathrm{~min}$, a well-known measure of early-phase insulin secretion during an OGTT $(15,16)$.

Mitochondrial ATP production by OXPHOS in the respiratory chain is necessary for glucose-stimulated insulin release by $\beta$-cells (17). Insulin secretion is impaired in pancreatic islets from patients with type 2 diabetes partially due to impaired hyperpolarization of the inner mitochondrial membrane and a failure to respond with a rise in ATP levels (18), but the number of identified polymorphisms in genes of the OXPHOS process associated with type 2 diabetes and its risk factors are limited.

Recent GWAS have focused on identifying genes associated with type 2 diabetes and, today, more than 35 common variants have been identified that affect the risk of the disease $(13,19-28)$. Although many of these variants seem to affect the $\beta$-cell function and insulin secretion $(29,30)$, only a few GWAS have included measurements of glucose-stimulated insulin secretion (31). Due to the importance of OXPHOS in the regulation of insulin secretion, we examined if common variants near nuclear-encoded genes of the respiratory chain affect glucose-stimulated insulin secretion, using data from a GWAS, the DGI. The identification of variants was based on one trait and for variants in genes of one specific molecular pathway. Among variants near genes of the respiratory chain, rs606164 and rs1323070 showed the strongest associations with insulinogenic index in DGI. Although these associations were not genome-wide significant in the DGI, one should keep in mind that the study was underpowered for these associations, as they could only reliably be assessed for non-diabetic individuals. We therefore used a lower threshold for selection of SNPs for replication in an independent study, PPP-Botnia. Our inclusion criterium was to identify SNPs near nuclear-encoded OXPHOS genes, which are associated with insulinogenic index with $P \leq 0.01$ and a $\mathrm{MAF} \geq 0.05$. Nine variants fulfilled the criterium.

To confirm the association of the two top hits, we replicated the results in a more extensive populationbased cohort, the PPP-Botnia study from Western Finland (14). In accordance with DGI, C-allele carriers of rs606164 showed decreased insulin secretion and there was a nominal association between rs1323070 and insulin secretion in PPP-Botnia. This effect was maintained when adjusting for insulin resistance by using disposition index. The inclusion of individuals with impaired fasting glucose (IFG) in PPP-Botnia did not affect our findings, since an association between rs606164 and insulinogenic index as well as a trend towards association for rs1323070 was observed even when individuals with IFG were excluded.

The common variant rs606164 is located $12 \mathrm{~kb}$ upstream of the NDUFC 2 gene, a position where genetic

Table 3 Effects of rs606164 and rs 1323070 on insulinogenic index in non-diabetic individuals of the PPP-Botnia study. Data are expressed as median (IQR). $\beta$ coefficiants (S.E.M.) are from linear regression analyses adjusted for age, sex and BMI based on an additive model.

\begin{tabular}{|c|c|c|c|c|c|c|c|c|}
\hline \multirow{3}{*}{$\begin{array}{l}\text { Study } \\
\text { PPP-Botnia } \\
\quad(n=4201)\end{array}$} & \multirow{3}{*}{$\begin{array}{l}\text { SNP } \\
\text { rs606164 }\end{array}$} & Phenotype & \multicolumn{3}{|c|}{$\begin{array}{c}\text { Genotypes } \\
\text { (genotype frequency) }\end{array}$} & \multirow{3}{*}{$\begin{array}{c}\beta \\
-0.070\end{array}$} & \multirow{3}{*}{$\begin{array}{l}\text { S.E.M. } \\
0.022\end{array}$} & \multirow{3}{*}{$\frac{P \text { value }}{0.002}$} \\
\hline & & & GG (0.024) & CG (0.285) & CC (0.691) & & & \\
\hline & & $\begin{array}{l}\text { Insulinogenic } \\
\text { index }\end{array}$ & $19.08(14.54)$ & $16.42(15.92)$ & $15.63(16.13)$ & & & \\
\hline $\begin{array}{l}\text { PPP-Botnia } \\
\qquad(n=4140)\end{array}$ & rs1323070 & $\begin{array}{l}\text { Insulinogenic } \\
\text { index }\end{array}$ & $\begin{array}{l}\text { AA }(0.432) \\
16.17(16.13)\end{array}$ & $\begin{array}{l}\text { AG }(0.441) \\
15.90(15.81)\end{array}$ & $\begin{array}{l}\text { GG }(0.127) \\
15.25(15.17)\end{array}$ & -0.040 & 0.021 & 0.05 \\
\hline
\end{tabular}


variation may influence gene transcription. NDUFC2 encodes NADH dehydrogenase (ubiquinone) 1 subunit C2, which is located in complex I of the electron transport chain. Complex I is the largest component of the OXPHOS system and entry point of electrons from $\mathrm{NADH}$ into the electron transport chain, thereby playing a key role in regulating OXPHOS. NDUFC2 and its flanking genes, thyroid hormone responsive (THRSP) and asparagine-linked glycosylation 8 (ALG8), appear to be conserved among chickens, humans, mice and rats. Since rs606164 are in LD with SNPs located in both THRSP and ALG8, we cannot exclude that the effect on insulin secretion is mediated by these genes. However, based on the function of these genes, they are not likely to be involved in the regulation of insulin secretion, and we therefore suggest that the found association between rs606164 and insulinogenic index is mediated via NDUFC2.

The position of rs1323070 is $\sim 24 \mathrm{~kb}$ downstream of COX7A2. COX7A2 encodes cytochrome $c$ oxidase VIIa polypeptide 2, which is located in complex IV of the electron transport chain. Complex IV catalyses the electron transfers from cytochrome $c$ to the reduction of oxygen to water. Although the location of rs1323070 is downstream of COX7A2 and not in LD with any SNP within this OXPHOS gene, it may affect the expression of COX7A2. It is also possible that rs 1323070 influences a gene upstream of the SNP or a so far unknown regulatory region that mediates the effect on insulin secretion. Taken together, common polymorphisms in or near genes involved in OXPHOS may be of importance in insulin secretion and/or the pathogenesis of type 2 diabetes.

In conclusion, we have identified two polymorphisms associated with glucose-stimulated insulin secretion in vivo. These polymorphisms, rs606164 and rs1323070, are located adjacent to nuclear-encoded genes involved in OXPHOS. This is an exploratory follow-up study of a published GWAS, DGI, where we have selected SNPs nominal associated with insulin secretion for replication in an independent study. It remains to be shown whether the findings can be replicated in even larger studies and influence the risk of type 2 diabetes.

\section{Supplementary data}

This is linked to the online version of the paper at http://dx.doi.org/10. 1530/EJE-10-0995.

\section{Declaration of interest}

The authors declare that there is no conflict of interest that could be perceived as prejudicing the impartiality of the research reported.

\section{Funding}

The DGI GWAS study was supported by a grant from Novartis. The investigation in Malmö was supported by grants from the Swedish
Research Council, Region Skåne, Malmö University Hospital, Knut and Alice Wallenberg Foundation, Diabetes Foundation, EFSD-Lilly, Tore Nilsson, Novo Nordisk, Söderberg, Påhlsson and Linné grant (B31 5631/2006).

\section{Acknowledgements}

We are grateful to the DGI research group for allowing us to use the DGI database.

\section{References}

1 Mulder H \& Ling C. Mitochondrial dysfunction in pancreatic betacells in type 2 diabetes. Molecular and Cellular Endocrinology 2009 297 34-40. (doi:10.1016/j.mce.2008.05.015)

2 Kelley DE, He J, Menshikova EV \& Ritov VB. Dysfunction of mitochondria in human skeletal muscle in type 2 diabetes. Diabetes 200251 2944-2950. (doi:10.2337/diabetes.51.10.2944)

3 Henquin JC. Regulation of insulin secretion: a matter of phase control and amplitude modulation. Diabetologia 200952 739-751. (doi:10.1007/s00125-009-1314-y)

4 Scarpulla RC. Transcriptional paradigms in mammalian mitochondrial biogenesis and function. Physiological Reviews $2008 \mathbf{8 8}$ 611-638. (doi:10.1152/physrev.00025.2007)

5 Ling C, Del Guerra S, Lupi R, Ronn T, Granhall C, Luthman H, Masiello P, Marchetti P, Groop L \& Del Prato S. Epigenetic regulation of PPARGC1A in human type 2 diabetic islets and effect on insulin secretion. Diabetologia 200851 615-622. (doi:10.1007/s00125-007-0916-5)

6 van den Ouweland JM, Lemkes HH, Ruitenbeek W, Sandkuijl LA, de Vijlder MF, Struyvenberg PA, van de Kamp JJ \& Maassen JA. Mutation in mitochondrial tRNA(Leu)(UUR) gene in a large pedigree with maternally transmitted type II diabetes mellitus and deafness. Nature Genetics 19921 368-371. (doi:10.1038/ ng0892-368)

7 Saxena R, de Bakker PI, Singer K, Mootha V, Burtt N, Hirschhorn JN, Gaudet D, Isomaa B, Daly MJ, Groop L, Ardlie KG \& Altshuler D. Comprehensive association testing of common mitochondrial DNA variation in metabolic disease. American Journal of Human Genetics 200679 54-61. (doi:10.1086/504926)

8 Patti ME, Butte AJ, Crunkhorn S, Cusi K, Berria R, Kashyap S, Miyazaki Y, Kohane I, Costello M, Saccone R, Landaker EJ, Goldfine AB, Mun E, DeFronzo R, Finlayson J, Kahn CR \& Mandarino LJ. Coordinated reduction of genes of oxidative metabolism in humans with insulin resistance and diabetes: potential role of PGC1 and NRF1. PNAS 2003100 8466-8471. (doi:10.1073/pnas.1032913100)

9 Mootha VK, Lindgren CM, Eriksson KF, Subramanian A, Sihag S, Lehar J, Puigserver P, Carlsson E, Ridderstrale M, Laurila E, Houstis N, Daly MJ, Patterson N, Mesirov JP, Golub TR, Tamayo P, Spiegelman B, Lander ES, Hirschhorn JN, Altshuler D \& Groop LC. PGC-1alpha-responsive genes involved in oxidative phosphorylation are coordinately downregulated in human diabetes. Nature Genetics 200334 267-273. (doi:10.1038/ng1180)

10 Ronn T, Poulsen P, Tuomi T, Isomaa B, Groop L, Vaag A \& Ling C. Genetic variation in ATP5O is associated with skeletal muscle ATP50 mRNA expression and glucose uptake in young twins. PLOS ONE 20094 e4793. (doi:10.1371/journal.pone.0004793)

11 Ronn T, Poulsen P, Hansson O, Holmkvist J, Almgren P, Nilsson P, Tuomi T, Isomaa B, Groop L, Vaag A \& Ling C. Age influences DNA methylation and gene expression of COX7A1 in human skeletal muscle. Diabetologia $2008 \quad 51 \quad 1159-1168$. (doi:10.1007/ s00125-008-1018-8)

12 Ling C, Poulsen P, Simonsson S, Ronn T, Holmkvist J, Almgren P, Hagert P, Nilsson E, Mabey AG, Nilsson P, Vaag A \& Groop L. Genetic and epigenetic factors are associated with expression of 
respiratory chain component NDUFB6 in human skeletal muscle. Journal of Clinical Investigation 2007117 3427-3435. (doi:10. 1172/JCI30938)

13 Saxena R, Voight BF, Lyssenko V, Burtt NP, de Bakker PI, Chen H, Roix JJ, Kathiresan S, Hirschhorn JN, Daly MJ, Hughes TE, Groop L, Altshuler D, Almgren P, Florez JC, Meyer J, Ardlie K, Bengtsson Bostrom K, Isomaa B, Lettre G, Lindblad U, Lyon HN, Melander O, Newton-Cheh C, Nilsson P, Orho-Melander M, Rastam L, Speliotes EK, Taskinen MR, Tuomi T, Guiducci C, Berglund A, Carlson J, Gianniny L, Hackett R, Hall L, Holmkvist J, Laurila E, Sjogren M, Sterner M, Surti A, Svensson M, Tewhey R, Blumenstiel B, Parkin M, Defelice M, Barry R, Brodeur W, Camarata J, Chia N, Fava M, Gibbons J, Handsaker B, Healy C, Nguyen K, Gates C, Sougnez C, Gage D, Nizzari M, Gabriel SB, Chirn GW, Ma Q, Parikh H, Richardson D, Ricke D \& Purcell S. Genome-wide association analysis identifies loci for type 2 diabetes and triglyceride levels. Science 2007316 1331-1336. (doi:10. 1126/science.1142358)

14 Pyykkonen AJ, Raikkonen K, Tuomi T, Eriksson JG, Groop L \& Isomaa B. Stressful life events and the metabolic syndrome: the prevalence, prediction and prevention of diabetes (PPP)Botnia Study. Diabetes Care 201033 378-384. (doi:10.2337/ dc09-1027)

15 Seltzer HS, Allen EW, Herron AL Jr \& Brennan MT. Insulin secretion in response to glycemic stimulus: relation of delayed initial release to carbohydrate intolerance in mild diabetes mellitus. Journal of Clinical Investigation $1967 \quad 46 \quad 323-335$. (doi:10.1172/JCI105534)

16 Phillips DI, Clark PM, Hales CN \& Osmond C. Understanding oral glucose tolerance: comparison of glucose or insulin measurements during the oral glucose tolerance test with specific measurements of insulin resistance and insulin secretion. Diabetic Medicine 1994 11 286-292. (doi:10.1111/j.1464-5491.1994.tb00273.x)

17 Wiederkehr A \& Wollheim CB. Minireview: implication of mitochondria in insulin secretion and action. Endocrinology 2006147 2643-2649. (doi:10.1210/en.2006-0057)

18 Anello M, Lupi R, Spampinato D, Piro S, Masini M, Boggi U, Del Prato S, Rabuazzo AM, Purrello F \& Marchetti P. Functional and morphological alterations of mitochondria in pancreatic beta cells from type 2 diabetic patients. Diabetologia $2005 \quad \mathbf{4 8}$ 282-289. (doi:10.1007/s00125-004-1627-9)

19 Sladek R, Rocheleau G, Rung J, Dina C, Shen L, Serre D, Boutin P, Vincent D, Belisle A, Hadjadj S, Balkau B, Heude B, Charpentier G, Hudson TJ, Montpetit A, Pshezhetsky AV, Prentki M, Posner BI, Balding DJ, Meyre D, Polychronakos C \& Froguel P. A genome-wide association study identifies novel risk loci for type 2 diabetes. Nature 2007445 881-885. (doi:10.1038/nature05616)

20 Zeggini E, Weedon MN, Lindgren CM, Frayling TM, Elliott KS, Lango H, Timpson NJ, Perry JR, Rayner NW, Freathy RM, Barrett JC, Shields B, Morris AP, Ellard S, Groves CJ, Harries LW, Marchini JL, Owen KR, Knight B, Cardon LR, Walker M, Hitman GA, Morris AD, Doney AS, McCarthy MI \& Hattersley AT. Replication of genome-wide association signals in UK samples reveals risk loci for type 2 diabetes. Science 2007316 1336-1341. (doi:10.1126/science.1142364)

21 Scott LJ, Mohlke KL, Bonnycastle LL, Willer CJ, Li Y, Duren WL, Erdos MR, Stringham HM, Chines PS, Jackson AU, ProkuninaOlsson L, Ding CJ, Swift AJ, Narisu N, Hu T, Pruim R, Xiao R, Li XY, Conneely KN, Riebow NL, Sprau AG, Tong M, White PP, Hetrick KN, Barnhart MW, Bark CW, Goldstein JL, Watkins L, Xiang F, Saramies J, Buchanan TA, Watanabe RM, Valle TT, Kinnunen L, Abecasis GR, Pugh EW, Doheny KF, Bergman RN, Tuomilehto J, Collins FS \& Boehnke M. A genome-wide association study of type 2 diabetes in Finns detects multiple susceptibility variants. Science 2007316 1341-1345. (doi:10.1126/science. 1142382)

22 Steinthorsdottir V, Thorleifsson G, Reynisdottir I, Benediktsson R, Jonsdottir T, Walters GB, Styrkarsdottir U, Gretarsdottir S, Emilsson V, Ghosh S, Baker A, Snorradottir S, Bjarnason H, Ng MC, Hansen T, Bagger Y, Wilensky RL, Reilly MP, Adeyemo A, Chen Y, Zhou J, Gudnason V, Chen G, Huang H, Lashley K,
Doumatey A, So WY, Ma RC, Andersen G, Borch-Johnsen K, Jorgensen T, van Vliet-Ostaptchouk JV, Hofker MH, Wijmenga C, Christiansen C, Rader DJ, Rotimi C, Gurney M, Chan JC, Pedersen O, Sigurdsson G, Gulcher JR, Thorsteinsdottir U, Kong A \& Stefansson K. A variant in CDKAL1 influences insulin response and risk of type 2 diabetes. Nature Genetics 200739 770-775. (doi:10.1038/ng2043)

23 Zeggini E, Scott LJ, Saxena R, Voight BF, Marchini JL, Hu T, de Bakker PI, Abecasis GR, Almgren P, Andersen G, Ardlie K, Bostrom KB, Bergman RN, Bonnycastle LL, Borch-Johnsen K, Burtt NP, Chen H, Chines PS, Daly MJ, Deodhar P, Ding CJ, Doney AS, Duren WL, Elliott KS, Erdos MR, Frayling TM, Freathy RM, Gianniny L, Grallert H, Grarup N, Groves CJ, Guiducci C, Hansen T, Herder C, Hitman GA, Hughes TE, Isomaa B, Jackson AU, Jorgensen T, Kong A, Kubalanza K, Kuruvilla FG, Kuusisto J, Langenberg C, Lango H, Lauritzen T, Li Y, Lindgren CM, Lyssenko V, Marvelle AF, Meisinger C, Midthjell K, Mohlke KL, Morken MA, Morris AD, Narisu N, Nilsson P, Owen KR, Palmer CN, Payne F, Perry JR, Pettersen E, Platou C, Prokopenko I, Qi L, Qin L, Rayner NW, Rees M, Roix JJ, Sandbaek A, Shields B, Sjogren M, Steinthorsdottir V, Stringham HM, Swift AJ, Thorleifsson G, Thorsteinsdottir U, Timpson NJ, Tuomi T, Tuomilehto J, Walker M, Watanabe RM, Weedon MN, Willer CJ, Illig T, Hveem K, Hu FB, Laakso M, Stefansson K, Pedersen O, Wareham NJ, Barroso I, Hattersley AT, Collins FS, Groop L, McCarthy MI, Boehnke M \& Altshuler D. Meta-analysis of genome-wide association data and largescale replication identifies additional susceptibility loci for type 2 diabetes. Nature Genetics 200840 638-645. (doi:10. 1038/ng.120)

24 Yasuda K, Miyake K, Horikawa Y, Hara K, Osawa H, Furuta H, Hirota Y, Mori H, Jonsson A, Sato Y, Yamagata K, Hinokio Y, Wang HY, Tanahashi T, Nakamura N, Oka Y, Iwasaki N, Iwamoto Y, Yamada Y, Seino Y, Maegawa H, Kashiwagi A, Takeda J, Maeda E, Shin HD, Cho YM, Park KS, Lee HK, Ng MC, Ma RC, So WY, Chan JC, Lyssenko V, Tuomi T, Nilsson P, Groop L, Kamatani N, Sekine A, Nakamura Y, Yamamoto K, Yoshida T, Tokunaga K, Itakura M, Makino H, Nanjo K, Kadowaki T \& Kasuga M. Variants in KCNQ1 are associated with susceptibility to type 2 diabetes mellitus. Nature Genetics 2008 40 1092-1097. (doi:10.1038/ng.207)

25 Unoki H, Takahashi A, Kawaguchi T, Hara K, Horikoshi M, Andersen G, Ng DP, Holmkvist J, Borch-Johnsen K, Jorgensen T, Sandbaek A, Lauritzen T, Hansen T, Nurbaya S, Tsunoda T, Kubo M, Babazono T, Hirose $H$, Hayashi M, Iwamoto $\mathrm{Y}$, Kashiwagi A, Kaku K, Kawamori R, Tai ES, Pedersen O, Kamatani N, Kadowaki T, Kikkawa R, Nakamura Y \& Maeda S. SNPs in KCNQ1 are associated with susceptibility to type 2 diabetes in East Asian and European populations. Nature Genetics 200840 1098-1102. (doi:10.1038/ng.208)

26 Rung J, Cauchi S, Albrechtsen A, Shen L, Rocheleau G, CavalcantiProenca C, Bacot F, Balkau B, Belisle A, Borch-Johnsen K, Charpentier G, Dina C, Durand E, Elliott P, Hadjadj S, Jarvelin MR, Laitinen J, Lauritzen T, Marre M, Mazur A, Meyre D, Montpetit A, Pisinger C, Posner B, Poulsen P, Pouta A, Prentki M, Ribel-Madsen R, Ruokonen A, Sandbaek A, Serre D, Tichet J, Vaxillaire M, Wojtaszewski JF, Vaag A, Hansen T, Polychronakos C, Pedersen O, Froguel P \& Sladek R. Genetic variant near IRS1 is associated with type 2 diabetes, insulin resistance and hyperinsulinemia. Nature Genetics $2009 \mathbf{4 1}$ 1110-1115. (doi:10.1038/ng.443)

27 Dupuis J, Langenberg C, Prokopenko I, Saxena R, Soranzo N, Jackson AU, Wheeler E, Glazer NL, Bouatia-Naji N, Gloyn AL, Lindgren CM, Magi R, Morris AP, Randall J, Johnson T, Elliott P, Rybin D, Thorleifsson G, Steinthorsdottir V, Henneman P, Grallert H, Dehghan A, Hottenga JJ, Franklin CS, Navarro P, Song K, Goel A, Perry JR, Egan JM, Lajunen T, Grarup N, Sparso T, Doney A, Voight BF, Stringham HM, Li M, Kanoni S, Shrader P, Cavalcanti-Proenca C, Kumari M, Qi L, Timpson NJ, Gieger C, Zabena C, Rocheleau G, Ingelsson E, An P, O'Connell J, Luan J, Elliott A, McCarroll SA, Payne F, Roccasecca RM, Pattou F, 
Sethupathy P, Ardlie K, Ariyurek Y, Balkau B, Barter P, Beilby JP, Ben-Shlomo Y, Benediktsson R, Bennett AJ, Bergmann S, Bochud M, Boerwinkle E, Bonnefond A, Bonnycastle LL, BorchJohnsen K, Bottcher Y, Brunner E, Bumpstead SJ, Charpentier G, Chen YD, Chines P, Clarke R, Coin LJ, Cooper MN, Cornelis M, Crawford G, Crisponi L, Day IN, de Geus EJ, Delplanque J, Dina C, Erdos MR, Fedson AC, Fischer-Rosinsky A, Forouhi NG, Fox CS, Frants R, Franzosi MG, Galan P, Goodarzi MO, Graessler J, Groves CJ, Grundy S, Gwilliam R, Gyllensten U, Hadjadj S, Hallmans G, Hammond N, Han X, Hartikainen AL, Hassanali N, Hayward C, Heath SC, Hercberg S, Herder C, Hicks AA, Hillman DR, Hingorani AD, Hofman A, Hui J, Hung J, Isomaa B, Johnson PR, Jorgensen T, Jula A, Kaakinen M, Kaprio J, Kesaniemi YA, Kivimaki M, Knight B, Koskinen S, Kovacs P, Kyvik KO, Lathrop GM, Lawlor DA, Le Bacquer O, Lecoeur C, Li Y, Lyssenko V, Mahley R, Mangino M, Manning AK, MartinezLarrad MT, McAteer JB, McCulloch LJ, McPherson R, Meisinger C, Melzer D, Meyre D, Mitchell BD, Morken MA, Mukherjee S, Naitza S, Narisu N, Neville MJ, Oostra BA, Orru M, Pakyz R, Palmer CN, Paolisso G, Pattaro C, Pearson D, Peden JF, Pedersen NL, Perola M, Pfeiffer AF, Pichler I, Polasek O, Posthuma D, Potter SC, Pouta A, Province MA, Psaty BM, Rathmann W, Rayner NW, Rice K, Ripatti S, Rivadeneira F, Roden M, Rolandsson O, Sandbaek A, Sandhu M, Sanna S, Sayer AA, Scheet P, Scott LJ, Seedorf U, Sharp SJ, Shields B, Sigurethsson G, Sijbrands EJ, Silveira A, Simpson L, Singleton A, Smith NL, Sovio U, Swift A, Syddall H, Syvanen AC, Tanaka T, Thorand B, Tichet J, Tonjes A, Tuomi T, Uitterlinden AG, van Dijk KW, van Hoek M, Varma D, Visvikis-Siest S, Vitart V, Vogelzangs N, Waeber G, Wagner PJ, Walley A, Walters GB, Ward KL, Watkins H, Weedon MN, Wild SH, Willemsen G, Witteman JC, Yarnell JW, Zeggini E, Zelenika D, Zethelius B, Zhai G, Zhao JH, Zillikens MC, Borecki IB, Loos RJ, Meneton P, Magnusson PK, Nathan DM, Williams GH, Hattersley AT, Silander K, Salomaa V, Smith GD, Bornstein SR, Schwarz P, Spranger J, Karpe F, Shuldiner AR, Cooper C, Dedoussis GV, Serrano-Rios M, Morris AD, Lind L, Palmer LJ, Hu FB, Franks PW, Ebrahim S, Marmot M, Kao WH, Pankow JS, Sampson MJ, Kuusisto J, Laakso M, Hansen T, Pedersen O, Pramstaller PP, Wichmann HE, Illig T, Rudan I, Wright AF, Stumvoll M, Campbell H, Wilson JF, Bergman RN, Buchanan TA, Collins FS, Mohlke KL, Tuomilehto J, Valle TT, Altshuler D, Rotter JI, Siscovick DS, Penninx BW, Boomsma DI, Deloukas P, Spector TD, Frayling TM, Ferrucci L, Kong A, Thorsteinsdottir U, Stefansson K, van Duijn CM, Aulchenko YS, Cao A, Scuteri A, Schlessinger D, Uda M, Ruokonen A, Jarvelin MR, Waterworth DM, Vollenweider P, Peltonen L, Mooser V, Abecasis GR, Wareham NJ, Sladek R, Froguel P, Watanabe RM, Meigs JB, Groop L, Boehnke M, McCarthy MI, Florez JC \& Barroso I. New genetic loci implicated in fasting glucose homeostasis and their impact on type 2 diabetes risk. Nature Genetics 201042 105-116. (doi:10.1038/ng.520)

28 Voight BF, Scott LJ, Steinthorsdottir V, Morris AP, Dina C, Welch RP, Zeggini E, Huth C, Aulchenko YS, Thorleifsson G,
McCulloch LJ, Ferreira T, Grallert H, Amin N, Wu G, Willer CJ, Raychaudhuri S, McCarroll SA, Langenberg C, Hofmann OM, Dupuis J, Qi L, Segre AV, van Hoek M, Navarro P, Ardlie K, Balkau B, Benediktsson R, Bennett AJ, Blagieva R, Boerwinkle E, Bonnycastle LL, Bengtsson Bostrom K, Bravenboer B, Bumpstead S, Burtt NP, Charpentier G, Chines PS, Cornelis M, Couper DJ, Crawford G, Doney AS, Elliott KS, Elliott AL, Erdos MR, Fox CS, Franklin CS, Ganser M, Gieger C, Grarup N, Green T, Griffin S, Groves CJ, Guiducci C, Hadjadj S, Hassanali N, Herder C, Isomaa B, Jackson AU, Johnson PR, Jorgensen T, Kao WH, Klopp N, Kong A, Kraft P, Kuusisto J, Lauritzen T, Li M, Lieverse A, Lindgren CM, Lyssenko V, Marre M, Meitinger T, Midthjell K, Morken MA, Narisu N, Nilsson P, Owen KR, Payne F, Perry JR, Petersen AK, Platou C, Proenca C, Prokopenko I, Rathmann W, Rayner NW, Robertson NR, Rocheleau G, Roden M, Sampson MJ, Saxena R, Shields BM, Shrader P, Sigurdsson G, Sparso T, Strassburger K, Stringham HM, Sun Q, Swift AJ, Thorand B, Tichet J, Tuomi T, van Dam RM, van Haeften TW, van Herpt T, van Vliet-Ostaptchouk JV, Walters GB, Weedon MN, Wijmenga C, Witteman J, Bergman RN, Cauchi S, Collins FS, Gloyn AL, Gyllensten U, Hansen T, Hide WA, Hitman GA, Hofman A, Hunter DJ, Hveem K, Laakso M, Mohlke KL, Morris AD, Palmer CN, Pramstaller PP, Rudan I, Sijbrands E, Stein LD, Tuomilehto J, Uitterlinden A, Walker M, Wareham NJ, Watanabe RM, Abecasis GR, Boehm BO, Campbell H, Daly MJ, Hattersley AT, Hu FB, Meigs JB, Pankow JS, Pedersen O, Wichmann HE, Barroso I, Florez JC, Frayling TM, Groop L, Sladek R, Thorsteinsdottir U, Wilson JF, Illig T, Froguel P, van Duijn CM, Stefansson K, Altshuler D, Boehnke M \& McCarthy MI. Twelve type 2 diabetes susceptibility loci identified through largescale association analysis. Nature Genetics 201042 579-589. (doi:10.1038/ng.609)

29 Lyssenko V, Jonsson A, Almgren P, Pulizzi N, Isomaa B, Tuomi T, Berglund G, Altshuler D, Nilsson P \& Groop L. Clinical risk factors, DNA variants, and the development of type 2 diabetes. New England Journal of Medicine $20083592220-2232$. (doi:10.1056/ NEJMoa0801869)

30 Jonsson A, Isomaa B, Tuomi T, Taneera J, Salehi A, Nilsson P, Groop L \& Lyssenko V. A variant in the KCNQ1 gene predicts future type 2 diabetes and mediates impaired insulin secretion. Diabetes 200958 2409-2413. (doi:10.2337/db09-0246)

31 Rich SS, Goodarzi MO, Palmer ND, Langefeld CD, Ziegler J, Haffner SM, Bryer-Ash M, Norris JM, Taylor KD, Haritunians T, Rotter JI, Chen YD, Wagenknecht LE, Bowden DW \& Bergman RN. A genome-wide association scan for acute insulin response to glucose in Hispanic-Americans: the Insulin Resistance Atherosclerosis Family Study (IRAS FS). Diabetologia $2009521326-$ 1333. (doi:10.1007/s00125-009-1373-0)

Received 4 February 2011

Accepted 15 February 2011 